\title{
微小球衝突による黒鉛材料のスポール破壊
}

\author{
田邊靖博, 佐々木健一, 赤津隆, 安田榮一
}

（平成9年5月 16 日受理, 平成 9 年 8 月 20 日採択）

\section{Spall Fracture of Graphite Materials by Impact of a Small Projectile}

\author{
Yasuhiro TANABE, Ken-ichi SASAKI, Takashi AKATSU and Eiichi YASUDA
}

\begin{abstract}
Three types of polycrystalline graphites and two 2D-C/C composites were impacted by a steel projectile of 4$\mathrm{mm}$ diameter with a velocity of $0.7 \mathrm{~km} / \mathrm{s}$ to $1.7 \mathrm{~km} / \mathrm{s}$. The damage behavior by impact, especially, spallation of the materials were investigated through the measurement of scattered and spalled volumes, formation and propagation of stress wave, shape of scattered fragments (debris), and the observation of debris by a high speed camera. The followings were concluded : (1) Critical velocity of spallation in graphites increased with increasing their static strength and thickness of the specimen, (2) weak-bonded layers in 2D-C/C composite was easily debonded (peel-off) at the interfaces by impact, (3) in $\mathrm{C} / \mathrm{C}$ composites debonding region near the rear surface was larger in the case a projectile stopped in them than in the case it passed through them, (4) shock waves in graphites could be measured using acoustic emission sensor, (5) the size of the spalled fragments depended on the material properties even among polycrystalline graphites, and (6) a model of spalling process in a polycrystalline graphite was proposed.
\end{abstract}

KEYWORDS : Spall, Polycrystalline graphite, C/C composite, Impact damage,High speed camera

\section{1. はじめに}

セラミックス基複合材料, 中でも C/C複合材料は, ガスター ビンブレードへの応用研究が開始されている。C/C複合材料 をガスタービンブレード等として利用する場合, 静的な破壊 だけではなく異物粒子の衝突による動的な材料の損傷あるい は破壊（以下FOD：Foreign Object Damage）を考慮した設 計を行う必要がある1”。

現在までのFODに関する研究は, 主として金属材料あるい は繊維強化プラスチックス（以下FRP : Fiber Reinforced Plastics）について行われており，七ラミックスについても $\mathrm{Si}_{3} \mathrm{~N}_{4}$ を始めとするモノリシック材料については行われてい る2)-4)。しかし, これらの研究は, 主としてガス銃を用いてい るため $500 \mathrm{~m} / \mathrm{s}$ 付近までの低速度域での研究である。この速 度域でセラミックスに生じる損傷はクラックが主となり, 接 触理論を用いて接触破壊を衝撃損傷と結びつけた解析がなさ れてきた。これら損傷状態は, 試料として用いたセラミック

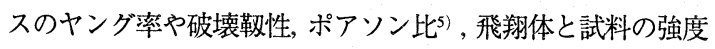
比, 硬さの比吕などと密接な関係があると考えられている。 高速域 $(1.0 \mathrm{~km} / \mathrm{s}$ 以上) になると損傷の様相はまったく異な ってくることが予想される。しかし, $1.0 \mathrm{~km} / \mathrm{s}$ 以上の高速衝突 の研究は,筆者らの調べた限りほとんど報告されていない》。

今後, $\mathrm{C} / \mathrm{C}$ 複合材料を始めとしてセラミックスをFODが問
題となる用途に利用拡大するためには, 異物粒子との衝撃損 傷を解明することは不可欠である。前述したようにセラミッ クスのFODに関する既往の研究はそのほとんどが低速度域 $(500 \mathrm{~m} / \mathrm{s}$ 以下) で行われ, 衝撃損傷を静的な物性値から類推し ようというものである。高速で回転するガスタービンのロー

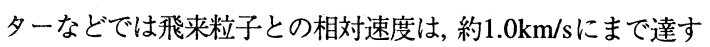
る。工業的な安全率を考慮に入れるとより高速な $(2.0 \mathrm{~km} / \mathrm{s}$ 程度まで) 衝突試験を行う必要がある。著者らは, 飛翔体と してMn-Znフェライト球あるいはスチール球を用いて黒鉛材 料へ約 $1.7 \mathrm{~km} / \mathrm{s}$ までの衝撃試験を行い, 衝撃損傷を静的機械的 特性と結びつけてきだ).9)。この結果, 黒鉛材料ではスポール 破壊が発生し, 衝突速度がある值以上になるとスポール破壊 による質量欠損は衝突速度に依存せず一定となることを示し た。スポール破壊で生じた破片は, 部材の破損だけではなく, 装置そのものの破壊を誘発する危険性を含んでいる。したが って, スポール破壊に関する知見を得ることは, 非常に重要で ある。

そこで, 本研究では, 球状飛翔体を用いた衝撃試験を行い, C/C複合材料ならびに黒鉛材料への高速粒子の衝突によるス ポール破壊を中心とした衝撃損傷を評価するための基礎を構 築することを目的として, 応力波の伝播, スポール破壊破片の 観察などの実験を行った。 


\section{2. 実験方法}

\section{1 衝撃試験}

2段式軽ガス銃（HS-2B：NRD製）を用いて, 直径 $4 \mathrm{~mm}$ の スチール球 (密度: $7.8 \mathrm{~g} / \mathrm{cm}^{3}$, ビッカース硬さ $: 7.0 \mathrm{GPa}$ (JISR1610-1991標記：7000HV），質量0.261g）を飛翔体と して円柱形試料の中心に衝突させた。飛翔体速度は, $0.7 \mathrm{~km} / \mathrm{s}$ $\sim 1.7 \mathrm{~km} / \mathrm{s}$ の範囲とした。2段式軽ガス銃の動作原理ならびに 実験方法の詳細は, 文献（8）に記してあるのでそちらを参照 されたい。

試料には, 密度が同程度で組織の異なる多結晶黒鉛 (G151A, G347, G540) ならびに2D-C/C-A, 2D-C/C-Bを用い た。用いた試料の特性をTable 1に示す。C/C複合材料の場 合, 寸法の制約から飛翔体進行方向に対し繊維配向方向が垂 直になる試料を使用した。試料寸法は, C/C複合材料が直径 $65 \mathrm{~mm}$ で厚さ $20 \mathrm{~mm}$ と $30 \mathrm{~mm}$, 黒鉛材料が直径 $65 \mathrm{~mm}$ で厚さ $20 \mathrm{~mm}, 30 \mathrm{~mm}$ と $40 \mathrm{~mm}$ である。

まず, 衝撃損傷を質量欠損と試料密度から求めた飛散容積 で評価した。飛翔体速度が高速になると衝突面と反対の面 (以下試料後面) にスポール破壊（試料後面側に観察される 損傷あるいは破壊）が発生する。本実験では,このスポール 破壊の容積を測定するために回収容器を用いて試料後面から 飛散する破片の回収を行った。

スポール破壊した領域あるいはクレータ（飛翔体衝突面 （前面）側にできる窪み状の損傷領域）を含む横断面を光学 顕微鏡を用いて観察した。試料の切断には, 刃厚 $0.8 \mathrm{~mm}$ の炭 化珪素製回転式カッター刃を用いた。

多結晶黒鉛材料に微小球を高速で衝突させた場合, クレー 夕およびスポール破壊領域は, 試料の中側に頂点を持つ円錐 状となる8，9)。結果の項で詳しく述べるが, 本実験では条件に よってはクレータとスポール破壊の明瞭な境界が観察できな い場合があった。この場合, 便宜的に, 試料前面側での損傷 · 破壊領域をクレータ, 後面側での損傷・破壊をスポール破壊
と呼ぶ。

\section{2 応力波伝播速度}

本実験ではスポール破壊をもたらす応力波の伝播を調べる ため, 試料後面の三カ所に歪みゲージとAE (Acoustic Emission）センサを貼付け, 到達時間の相違と飛翔体との衝 突点との距離から試料内部を伝播する圧縮応力波の伝播速度 を計測した。

本実験で用いた歪みゲージは, (株昭和測器社製のゲージ長 さ2mmの1軸歪みゲージ（N11-FA-2-120-11-VSE1），AEセ ンサは, (株)NF回路設計ブロック社製の広帯域形AEセンサ (AE-900M-WB) である。スポール破壊が生じることによっ て正確な波形が取れなくなることを防ぐため, スポール破壊 を起こさない条件（飛翔体速度と試料厚さ）で実験を行った。 また, 伝播形態を推察する目的から, 等方質に近いと考えられ る多結晶黒鉛材料のみを試料として用いた。AEセンサの取 付け位置が歪みゲージの位置と重ならないように, 1つの試料 に対し歪みゲージを2つ, AEセンサを1つ取り付けた。

歪みゲージ, AEセンサの波形はそれぞれアンプを通してオ シロスコープ（横河電機株式会社製DL1540）に表示させ,パ ーソナルコンピュータ上で処理を行った。トリガーとして飛 翔体速度計測で使用する誘導起電力の出力波形を用いた。歪 みゲージ信号は, Low Pass Filter (200kHz) を通して出力し た。一方, AEセンサ信号は, High Pass Filter（100kHz）, Low Pass Filter (2MHz) を通して出力した。試料後面に到達す る波は周波数がまったく不明なため, 歪みゲージ, AEならび に各アンプの特性を考慮に入れて低周波数の波は歪みゲー ジ, 高周波数の波はAEで捉えられる設定となる様に心がけ た。

\section{3 破片分布ならびに破片撮影}

スポール破壊によって試料後面から飛散した破片（以下破 片とはすべてスポール破壊によって生じたものを指す）の寸 法分布を知るために, 回収した破片から0.01g以上の破片の質 量ヒストグラムを作成した。

Table 1 Mechanical Properties of graphites and C/C composites used in this study.

\begin{tabular}{|c|c|c|c|c|c|}
\hline Specimen & $\begin{array}{l}\begin{array}{l}\text { Bulk } \\
\text { density }\end{array} \\
\mathrm{g} / \mathrm{cm}^{3}\end{array}$ & $\begin{array}{c}\text { Bending } \\
\text { Strength } \\
\mathrm{MPa} \\
\end{array}$ & $\begin{array}{l}\begin{array}{l}\text { Elastic } \\
\text { modulus }\end{array} \\
\qquad \mathrm{GPa} \\
\end{array}$ & $\begin{array}{l}\text { Inter-layer } \\
\text { shear } \\
\text { strength } \\
\quad \mathrm{MPa} \\
\end{array}$ & $\begin{array}{l}\text { Maximum } \\
\text { particle } \\
\text { size } \\
\quad \mathrm{mm} \\
\end{array}$ \\
\hline G151A & 1.80 & 27 & 12.5 & & 1.0 \\
\hline G347 & 1.85 & 49 & 13.8 & & 0.1 \\
\hline G540 & 1.85 & 98 & 15.0 & & 0.01 \\
\hline 2D-C/C-A & 1.65 & 206 & $\begin{array}{l}117(\mathrm{~T}) \\
195(\mathrm{P})\end{array}$ & 12.4 & \\
\hline 2D-C/C-B & 1.60 & 81 & $\begin{array}{l}56(\mathrm{~T}) \\
68(\mathrm{P})\end{array}$ & 18.0 & \\
\hline
\end{tabular}

Shear strength is measured by a double notched compression method.

Elastic modulus is measured using a strain-gage.

$\mathrm{T}$ : Transversal, $\mathrm{P}$ : Parallel to the cloth-plane direction. 
高速度カメラFlashCam（PCO Computer Optics GmbH）を 用いてスポール破壊によって飛散する破片を観察した。カメ ラは, 破片の飛散軌跡が見えるように飛散体の運動方向に対 し垂直に設置した。露光時間はすべて50 的とした。遅延時間 は, 後面での応力波 (AE) 到達時からの時間としてカメラ側 で設定した。

\section{3. 結果と考察}

\section{1 飛散容皘}

多結晶黑鉛における飛散容積と試料材質との関係をFig.1 に示す。 $20 \mathrm{~mm}, 30 \mathrm{~mm}$ 厚試料ともに, G540>G347> $151 \mathrm{~A}$ の順に容積が小さくなった。クレータの生成8) と同様に, 有 効破壊エネルギおよび散逸エネルギの割合が大きくなるにつ れ飛散容積が小さくなった。厚さが $40 \mathrm{~mm}$ と厚くなると, ク レータの場合 ${ }^{8)}$ と異なり,材質による飛散容積の違いが明確 では無くなった。

$\mathrm{C} / \mathrm{C}$ 複合材料の結果を同じくFig.1に示す。飛散容積は明ら かにC/C複合材料の方が小さい。C/C複合材料間の試料材質 による飛散容積に差が現れないのは静的機械的特性に大きな 差がないことに対応していると考えられる。また, 試料厚さ による違いが小さい。衝撃エネルギ250J以下の試料では, 衝
撃エネルギにも依存していない。

これらの現象は, 定性的には, 次の様に説明できる。実際に は, 飛散容積は試料の力学特性, 試料厚さならびに飛翔体の運 動エネルギ（衝撃エネルギ）の関数であると推察される。あ る程度以上の厚さになると, 飛翔体は試料内で大きな抵抗を 受けて減速する。スポール破壊は, 飛翔体が直接引き起こす 破壊ではなく, 飛翔体と材料との衝突時に発生する圧力が大 きな役割を果たしている。本実験の範囲では, 密度を揃えて この圧力差が小さくなるように材質を選定してある。したが って, 材料と飛翔体との直接的な相互作用で発生するクレー 夕容積には大きな材質依存が認められるが, 飛散容積の大部 分を占めるスポール容積では材質依存が少なくなる。その結 果として, 厚い試料では飛散容積に大きな材質依存性が認め られない。

\section{2 横断面の钼察}

黒鉛材料の結果をFig.2に示す。G151A, G347, G540のス ポール破壞は, 形状が異なることがわかる。G347ではスポー 儿破壊した領域の外側に大きな亀裂が発生していた。この亀 裂は試料後面からクレーターとスポール破壊の境界に向けて 伸びており,準静的な押し込みによって生じるコーンクラッ クや寺前ら ${ }^{10)}$ の実験で生じたパーカッションコーンの様に
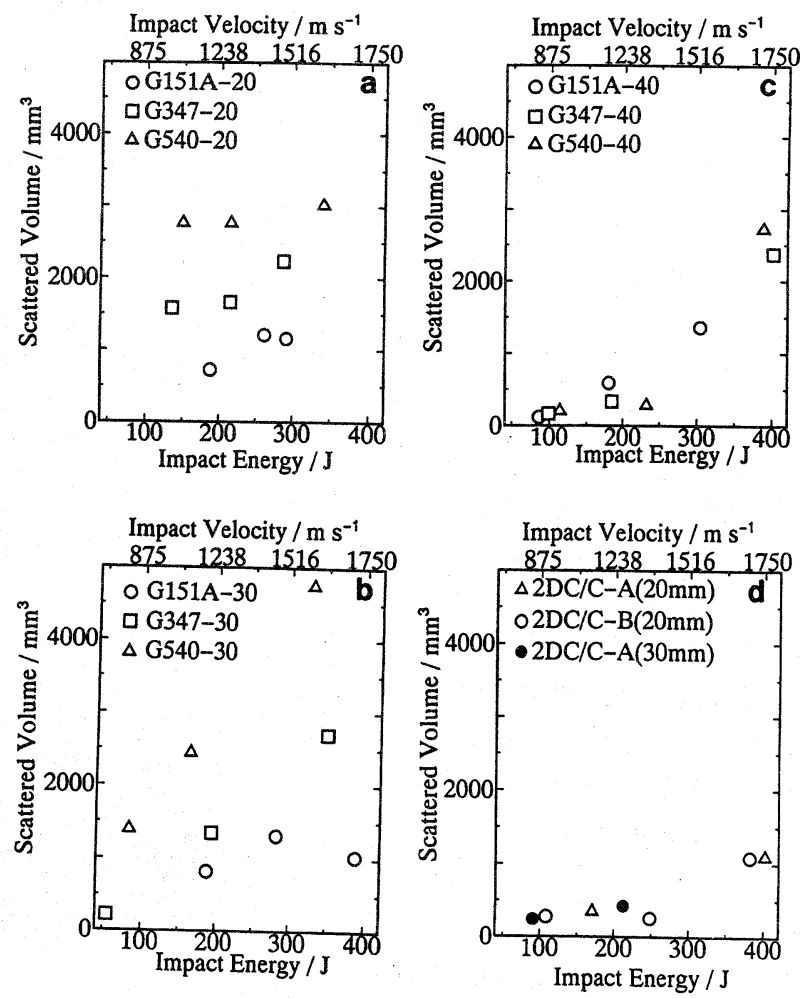

Fig.1 Scattered volume of the graphites and c/ccomposites as a function of impact energy. (a) graphite in 20mm thickness, (b) graphite in $30 \mathrm{~mm}$ thickness, (c) graphite in $40 \mathrm{~mm}$ thickness, (d) C/C composites. 


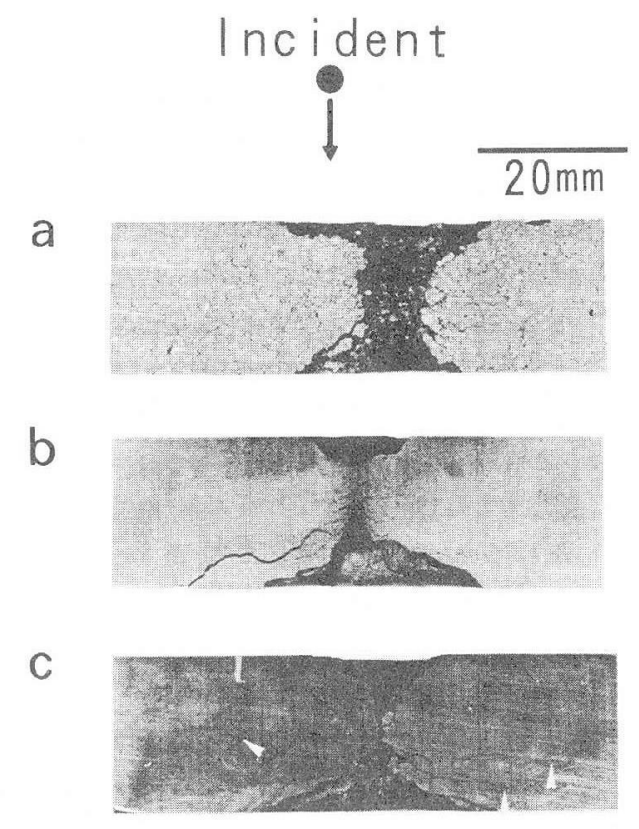

Fig.2 Cross sectional view of $20-\mathrm{mm}$ thick graphites. (a) G151A impacted at $1090 \mathrm{~m} / \mathrm{s}$, (b) G347 impacted at $1020 \mathrm{~m} / \mathrm{s}$, (c) $\mathrm{G} 540 \mathrm{impacted}$ at $1070 \mathrm{~m} / \mathrm{s}$.

衝突面の応力によって生じる龟裂とは異なるものである。ま た, 写真では確認し難いが，G540の横断面には比較的多数の 長い亀裂 (矢印) が生成していた。これらの大きな龟裂は, G151Aには認められないことから, スポール破壊に扔いても， クレータ生成と同様に準静的な有効破壤エネルギの大小で龟 裂の生成が説明できる。

$\mathrm{C} / \mathrm{C}$ 複合材料の結果をFig.3, 4に示す。 $20 \mathrm{~mm}$ 厚C/C複合材 料試料同士を比較すると, $1140 \mathrm{~m} / \mathrm{s}$ で飛翔体を衝突させた $2 \mathrm{D}$ C/C-A（Fig.3-a）では, 層間剥離が試料後面付近で広範囲に 広がり, 剥離部分は後面付近が最も大きくクレータの底に向 かって徐々に小さくなっている。これはFRPで見られる逐次 的層間剥離メカニズムと同様の現象と推察される ${ }^{11\rangle}$ 。一方, $1700 \mathrm{~m} / \mathrm{s}$ 付近では飛翔体は試料を貫通する。この試料では, 飛翔体が通過した後面付近に繊維の大きな捲れが観察される が, 試料に明確な層間剥離は見られない (Fig.3-b)。飛翔体 の貫通の有無により破壊挙動が異なることが示された。亀裂 の進展速度以上で飛翔体が試料内を進行する場合, 亀裂が進 展し終わる前に飛翔体が試料から飛び出すことは容易に想像 される。亀裂の発生場所と龟裂進展速度あるいは飛翔体速度 との関係は, 現時点では不明であるが, 今後の重要な検討課題 である。

飛翔体が貫通した2D-C/C-Aと2D-C/C-Bとを比較すると, 2D-C/C-Aの方が, 試料後面の繊維の捲れは大きい (Fig.3-b, c)。30mm厚試料同士を比較すると, 2D-C/C-Aでは中心付近 で完全な層間剥離が発生している (Fig.4)。2D-C/C-Bでは, 2D-C/C-Aと比較して衝突速度が遅いにもかかかわらず, 2 カ

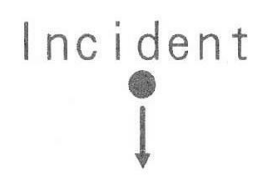

a

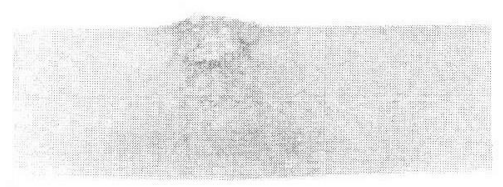

b

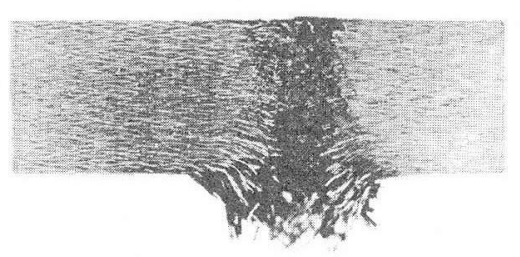

C

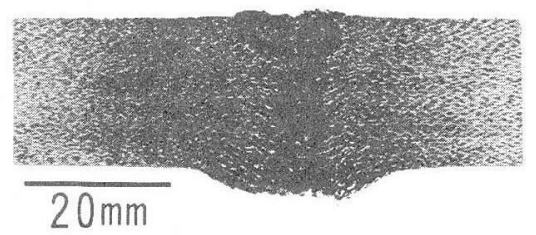

Fig.3 Cross sectional view of 20 -mm thick C/C composites.

(a) $2 \mathrm{D}-\mathrm{C} / \mathrm{C}-\mathrm{A}$ impacted at $1140 \mathrm{~m} / \mathrm{s}$, (b) $2 \mathrm{D}-\mathrm{C} / \mathrm{C}-$ A impacted at $1750 \mathrm{~m} / \mathrm{s}$, (c) $2 \mathrm{D}-\mathrm{C} / \mathrm{C}-\mathrm{B}$ impacted at $1710 \mathrm{~m} / \mathrm{s}$.
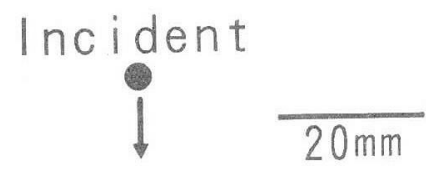

a

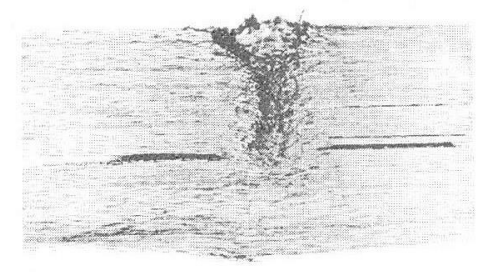

b

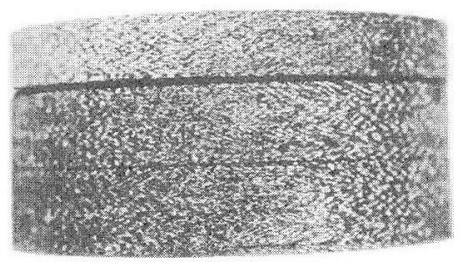

Fig.4 Delamination of $30-\mathrm{mm}$ thick $\mathrm{C} / \mathrm{C}$ composites. (a) 2D-C/C-A impacted at $1790 \mathrm{~m} / \mathrm{s}$, (b) $2 \mathrm{D}-\mathrm{C} / \mathrm{C}-\mathrm{B}$ impacted at $1270 \mathrm{~m} / \mathrm{s}$. 
所で大きな剥離を起こしている。30mm厚の2D-C/C-Bは一 度熱圧成形したC/C複合材料の間にプリプレグシートを挟ん で数個重ねた後に, 再度, 熱圧成形したものである。界面接着 強度の弱いと推察される（プリプレグシート面での剪断強 度：8.0MPa）プリプレグシート上で剥離が発生したためと 考えられる。一方, 2D-C/C-A は, 一回の熱圧成形で作られて いるため接着強度の特に弱い界面は存在しない。2D-C/C-A の中央付近の剥離は, 飛翔体が停止した付近で生じており, 希 薄波（圧縮衝撃波が試料後面で反射し, 膨張（引張）希薄波 として試料内部に戻ってくる）によって生じた層間剥離とは 考えにくい。この層間剥離は, 飛翔体貫入によって発生する 応力によって直接的に発生したものと考えられる。厚い試料 では衝撃エネルギーを試料内部の数力所に生じる大きな剥離 と, 希薄波がもたらす試料後面付近の層間剥離とで消費する ことが示唆される。

\section{3 スポール臨界点}

40mm試料でスポール臨界速度を比較すると, G540> G347>G151Aの順で小さくなっている（Table 2)。G540>

Table 2 Critical velocity for spallation.

\begin{tabular}{lr}
\hline \multicolumn{1}{c}{ Specimen } & Critical velocity \\
\hline G151A-20mm & $<1020 \mathrm{~m} / \mathrm{s}$ \\
G347-20mm & $<1027 \mathrm{~m} / \mathrm{s}$ \\
G540-20mm & $<1070 \mathrm{~m} / \mathrm{s}$ \\
G151A-30mm & $<1200 \mathrm{~m} / \mathrm{s}$ \\
G347-30mm & $650-1220 \mathrm{~m} / \mathrm{s}$ \\
G540-30mm & $1120-1590 \mathrm{~m} / \mathrm{s}$ \\
G151A-40mm & $810-1180 \mathrm{~m} / \mathrm{s}$ \\
G347-40mm & $1190-1750 \mathrm{~m} / \mathrm{s}$ \\
G540-40mm & $>1720 \mathrm{~m} / \mathrm{s}$ \\
2D-C/C-A-20mm & $<1140 \mathrm{~m} / \mathrm{s}$ \\
2D-C/C-B-20mm & $910-1380 \mathrm{~m} / \mathrm{s}$ \\
\hline The sign of inquality indicates \\
that the critical velocity is under \\
or above the indicated value.
\end{tabular}

G347>G151Aの順で曲け強度が低い（Table 1)。スポール 破壊臨界速度は, 静的な強度に対応した特性と捉えることが できる。

試料厚みとスポール臨界速度の関係について見ると, G347, G540では，厚くなるにつれスポール臨界速度は大きくなった (Table 2)。試料内を伝播する応力波の伝播距離が長いほど 減衰が大きくなるためと考えられる。残念ながら, G151Aで はスポール臨界速度が低いために, 今回の実験では厚みとの 関係を十分には検討できなかった。表中, 不等号で示してあ る值は, 臨界速度がそれ以上あるいはそれ以下であることを 示している。

$20 \mathrm{~mm}$ 厚試料のスポール容積は本実験範囲では衝撃エネル ギーに大きく依存しない $($ Fig.5)。試料が $30 \mathrm{~mm}$ と厚くなる と, G151Aでは20mm厚の試料と同様に飛散容積ならびにス ポール容積ともに衝撃エネルギーに大きく依存しない傾向を 示すが, 他の試料では衝撃エネルギーの増加に伴って, 飛散容 積ならびにスポール容積が増加する傾向を示し始めている。 詳細は, 今後の検討課題である。

複合材料のスポール破壊は, 希薄波の引張り応力による層 間剥離も含む(2) .13)。したがって, Fig.3の1140m/sでの層間剥 離は, スポール破壊である。Table 2では, 希薄波による層間 剥離もスポール破壊としてある。本実験の範囲では, 2D-C/C$\mathrm{A}$ よりも剪断強度の高い2D-C/C-Bの30mm厚試料においては 後面付近の層間剥離は起こらなかった。C/C複合材料におい ては, 剪断強度が高い材料ほど, 剥離破壊が少ない (小さい) ことが確かめられた。

\section{4 応力波伝播速度}

スポール破壊は試料後面に到達する圧縮応力波拉よびその 反射希薄波によって生じる。既往の研究では,これを計測す るのにさまざまな手法が用いられ, 武田らは歪みゲージ用い てFRPの応力波を計測し ${ }^{14)}$, Reedらは水晶振動子でFRPの応 力波 (衝撃波) を計測している ${ }^{15)}$ 。本研究においても, 圧縮
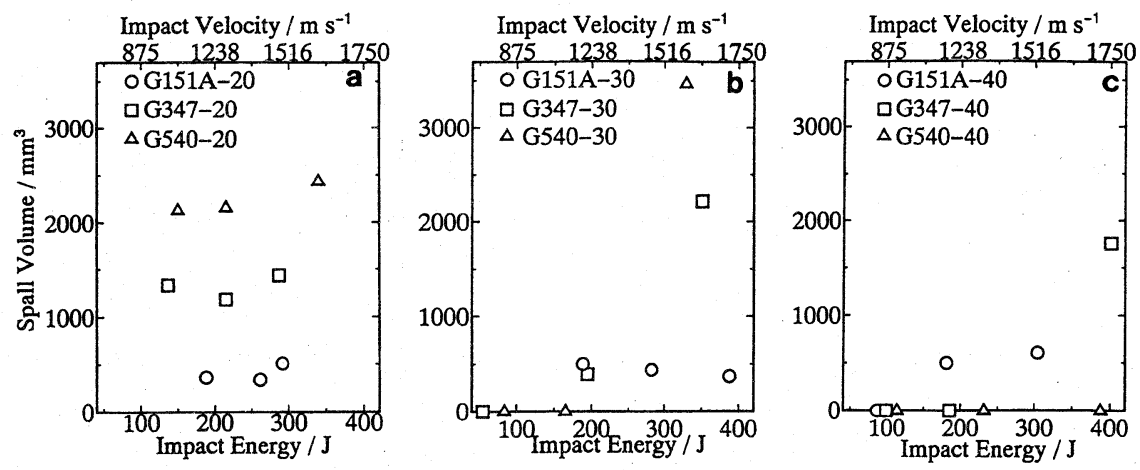

Fig.5 Spalled volume of the graphites as a function of impact energy. (a) 20-mm thickness, (b) 30-mm thickness, (c) 40-mm thickness. 
Table 3 Calculated velocities of the specimens from their elastic constants.

\begin{tabular}{lcc}
\hline Specimen & $\begin{array}{c}\text { Longitudinal } \\
\text { wave velocity } \\
\mathrm{m} / \mathrm{s}\end{array}$ & $\begin{array}{c}\text { Transversal } \\
\text { wave velocity } \\
\mathrm{m} / \mathrm{s}\end{array}$ \\
\hline G151A & 2635 & 1635 \\
G347 & 2731 & 1681 \\
G540 & 2847 & 1766 \\
2D-C/C-A (T) & 8421 & 5639 \\
2D-C/C-A (P) & 10871 & 6572 \\
2D-C/C-B (T) & 5916 & 3652 \\
2D-C/C-B (P) & 6519 & 3868 \\
\hline
\end{tabular}

$\mathrm{T}$ : Transversal, $\mathrm{P}$ : Parallel to the cloth-plane direction.

Table 4 Measured wave velocities.

\begin{tabular}{lcc}
\hline Specimen & $\begin{array}{c}\text { Wave velocity } \\
\mathrm{m} / \mathrm{s}\end{array}$ & $\begin{array}{c}\text { Impact velocity } \\
\mathrm{m} / \mathrm{s}\end{array}$ \\
\hline G151A & $600(\mathrm{SG})$ & 810 \\
G347 & $1040(\mathrm{SG})$ & 930 \\
& $1000(\mathrm{SG})$ & 930 \\
G540 & $610(\mathrm{SG})$ & 870 \\
& $670(\mathrm{SG})$ & 870 \\
& $3370(\mathrm{AE})$ & 1330 \\
\hline
\end{tabular}

SG : Strain gage, $\mathrm{AE}:$ Acoustic emission sensor

応力波を歪みゲージとAEを用いて実験的に計測し, スポール 破壊との関係について調べた。

等方無限媒体を仮定して各材料の弾性定数, 密度を用いて 算出した縦波速度 ${ }^{16)}$ と横波速度 ${ }^{16)}$ を示す（Table 3)。応力 波伝播速度の測定結果をTable 4に示してある。AEで計測し た伝播速度は弾性波速度よりも速い（Table 4)。試料内部に 衝撃波が発生したと考えられる。Hugoniot ${ }^{17)}$ を用いて密度 $1.88 \mathrm{~g} / \mathrm{cm}^{3}$ の黒鉛にSUS304が $1.3 \mathrm{~km} / \mathrm{s}$ で衝突したときの衝撃 波速度を求めると $4.1 \mathrm{~km} / \mathrm{s}$ となる。今回は試料厚みが $40 \mathrm{~mm}$ と厚い試料であるため, 試料内部で分散が起こり, $3.4 \mathrm{~km} / \mathrm{s} に$ 減速したと推察できる。AEセンサーで黒鉛材料中の衝撃波 の到達を計測できることが分かった。

一方, 歪みゲージで計測した波は, 各試料とも異なる場所で ほぼ同じ伝播速度が得られ，その值はAEで求めた速度と比較 して遅くなった（Table 4)。歪みゲージで計測できた波の速 度は, 計算から求めた横波速度の半分以下である。本条件で は, 明らかにAEとは異なる波を計測している。

\section{5 破片分布}

$20 \mathrm{~mm}$ 厚試料を用いて $1600 \mathrm{~m} / \mathrm{s}$ 付近の速度で衝突させた時 の黒鉛材料の破片の質量ヒストグラムをFig.6に示す。今回 測定しなかうた0.01g未満の破片の質量の各々の試料での総 和は, 約 $0.8 \mathrm{~g}$ (G151A), 1.2g (G347), 1.8g (G540) であっ た。破片の個数は, G151AよりG540が多くなった。G347は その中間であった。また, G151A<G347<G540の順で大きな
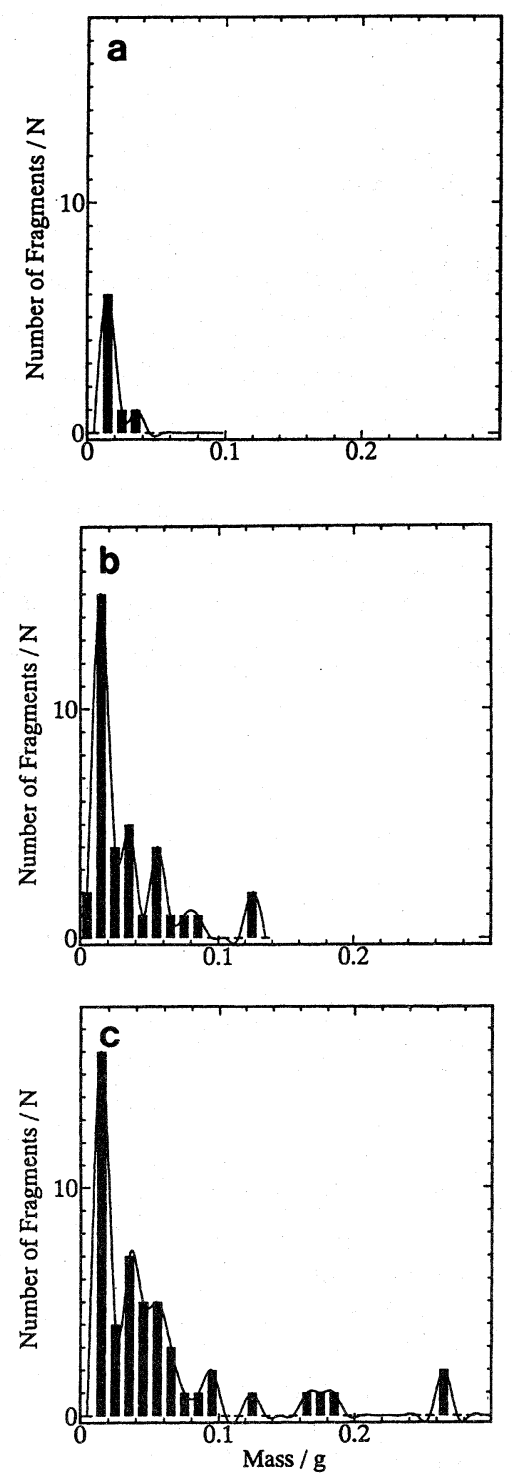

Fig.6 Histgrams in the number of spalled fragments above $0.01 \mathrm{~g}$ as a function of each mass. (a) G151A, (b) G347, (c) G540.

破片が数多く認められた。これらも有効破壊エネルギーで整 理できる。

\section{6 破片撮影}

G540の $20 \mathrm{~mm}$ 厚試料に約 $1500 \mathrm{~m} / \mathrm{s}$ で飛翔体を衝突させ, ス ポール破壞によって生じる破片が飛散している瞬間の写真撮 影に成功したので, その結果（Fig.7）について述べる。中心 付近に認められる円形の明るい部分に撮影用の照明を集中し てあてている。

スポール破壊直後の破片は, 貫通した飛翔体とともに中心

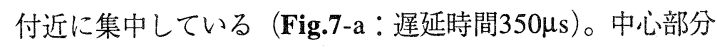
の閃光は, 写真撮影用の光源ではなく, 破片自身が高温で発生

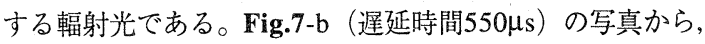



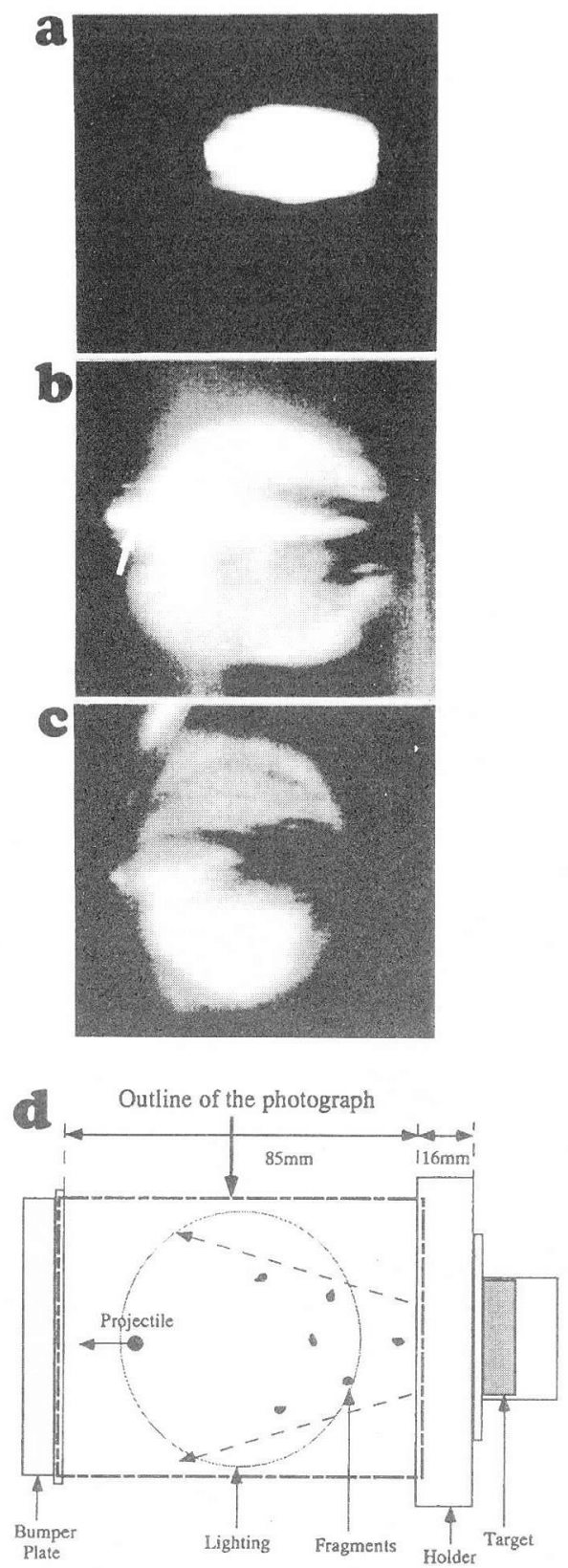

Fig.7 High speed photographs on spalled fragments from the rear surface of G540. (a) impacted at $1610 \mathrm{~m} / \mathrm{s}$ in $350 \mu_{\mathrm{s}}$ delay, (b) impacted at $1610 \mathrm{~m} / \mathrm{s}$ in $550 \mu_{\mathrm{s}}$ delay,

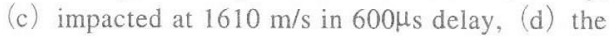
view for fragments' photographs.

破片が試料㣪面から放射状に飛散しているのがわかる(円形 の光源内に黑い軌跡として捉えられている)。写真左側の閃 光 (矢印) は, 飛翔体がバンパー板に衝突して跳ね返った軌 跡である。飛翔体の軌跡と外側の飛散破片とのなす角度は, 約 $14^{\circ}$ であった。この写真では, 飛翔体以外には, 閃光が認め られない。試料の温度は, 200us程度の短い時間でかなり低下
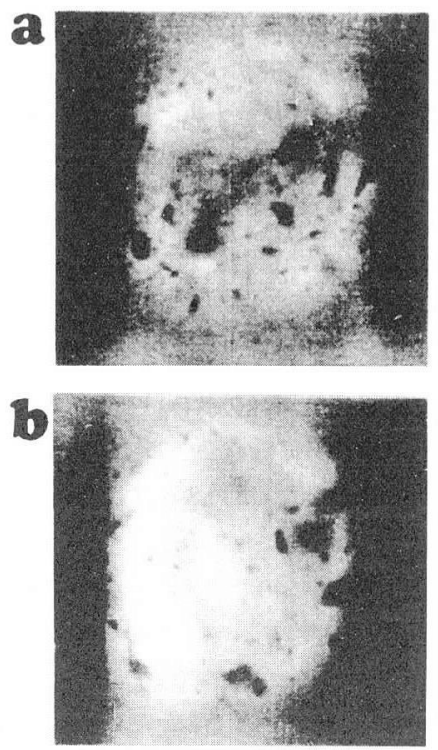

Fig.8 Video tape recorder photographs on spalled fragments from the rear surface of G540. (a) impacted at 1610 $\mathrm{m} / \mathrm{s}$, (b) after above $30 \mathrm{~ms}$ from the photo (a).

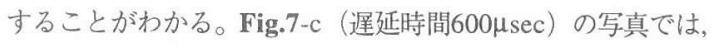
Fig.7-bで見られた中心付近に集中する破片が更に進んでき ているのがわかる。また, 総じて軌跡の長さが短く太くなっ ており, Fig.7-bで捉えられている破片と比較して速度が遅く 大きな破片が飛散している様子がわかる。

通常のビデオ (VTR) 撮影によって得られた写真をFig.8a, bに示す。Fig.8-bは, Fig.8-aから33ms後となる。これらの 写真ではスポール破壊が始まってからの正確な時間は分から ないが, Fig.7よりも十分遅い時間（30ms以上の時間遅れがあ る）であり，初期には見られない大きな破片が認められる。 また,この大きな破片は, Fig.7で羿められた小さな破片と比 較して, 広角度に分布していることがわかる。Fig.8は, 通常 のVTR撮影の1コマであり, シャッター開放（露出）時間は,

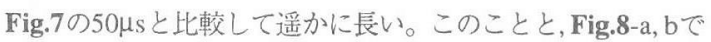
破片の輪郭が明確なことから,Fig.8-a,bの大きい破片はFig.7b, cで写っている破片と比べると遥かに低速で飛散している ことになる。

Fig.7-aでみられた明るい先端の軌跡が飛翔体であり, シャ ッター開放時間 $(50 \mathrm{~ms})$ を考えると, この間の平均速度は約 $600 \mathrm{~m} / \mathrm{s}$ となる。街撃速度の2.5分の1に減速している。Fig.7bから飛翔体は, 破片よりも速い速度で飛んでいることがわか る。先に算出した $600 \mathrm{~m} / \mathrm{s}$ は, 歪みゲージで捉えた波の速度と 同程度である。試料中を進む飛翔体は, $600 \mathrm{~m} / \mathrm{s}$ 以上であるこ とは明かである。したがって, 試料の破壊の大部分は, 飛翔体 か陚料を貫通した後に発生していることになる。Senf等は, K5 ガラスを用いて亀裂進展をもたらす波の速度は横波速度 以下であることを示し, 衝突速度が増加するにつれ, その波の 
速度は増加することを報告している18)。本実験では, 歪みゲ ージで測定した $600 \mathrm{~m} / \mathrm{s}$ 程度の波が, Senf等が指摘しているス ポール破壞を実際に引き起こす波に相当すると推察される。

\section{4. 黒鉛材料のスポールモデル}

質量ヒストグラム, 写真撮影の結果をまとめてG540（高強 度黑鉛材料) のスポール破壊発生過程のモデルを提案する。

写真撮影で始めに飛散する細かな破片は, 試料中心部分 （スポール破壤中心と仮定）から約 $14^{\circ}$ の角度であり，それか ら50 秒経過した後もほほ同程度の角度で大量の破片が飛散 していることが分かった。Fig.8-bから比較的大きな破片が 広範囲に飛散しているのがわかる。

これらの結果から, G540ではスポール破壊は, 大きく2つの 段階に分けることができる。第一段階では, 数多くの小さな 飛散破片が, スポール破壊中心から比較的小さな角度以内で 高速に飛散する。しばらく時間が経つと大きい破片が飛散す る第二段階となる。この破片は初期のものに比べて広い角度 で飛散し,その速度は非常に遅い。今回の実験ではFig.7-cか らFig.8-aまでの正確な時間差が分からないが,ビデオカメラ の性能を考えると $30 \mathrm{~ms}$ 以上の時問差があると考えられる。

Fig.9は回収した破片を元あったと考えられるところに戻 したものである。破片の寸法から考えて, 上の写真がスポー 儿破壞第一段階が終了し第二段階に移行した直後, 下が第二 段階が終了した後である。スポール破壞は第一段階と第二段 階とで破片の形状・法か変化している (Fig.7, 8,9)。大き な破片は, その形状から試料後面からスポール破壊の中心部 分に向かう亀裂が進展して飛散したことを伺わせる。スポー ル破壊が始まってから, 亀裂が進展して大きな破片が飛散す るまでに十分な時間がある。スポール破壊の第二段階は, 試 料後面から生じる大きな亀裂が試料内部, あるいは中心部に
向かって進展して, 破片として飛散する過程である。これら を図示するとFig.10で表せる。
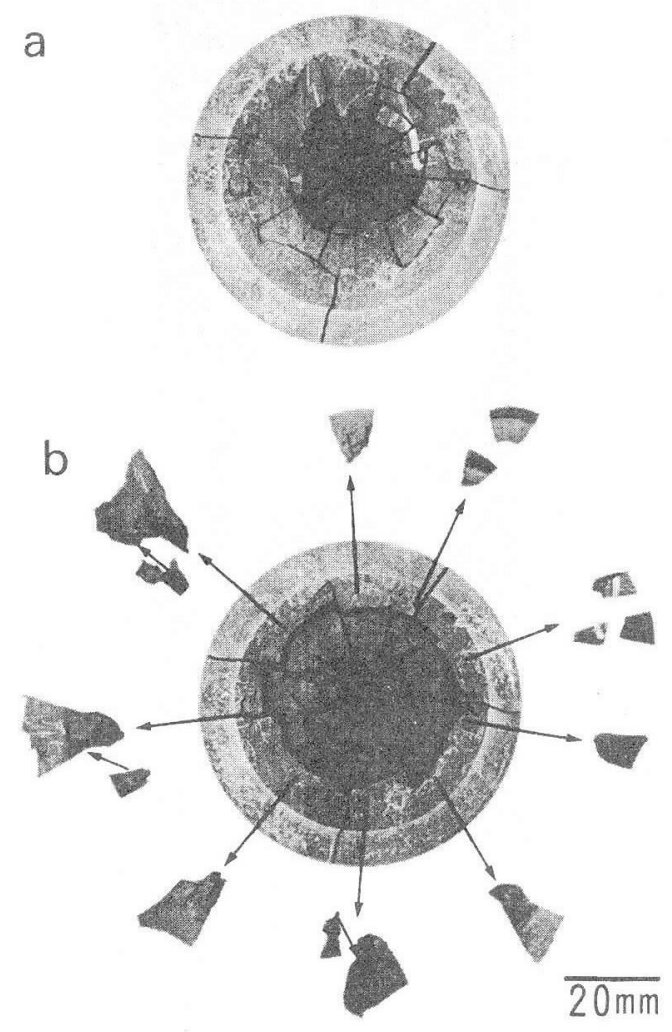

Fig.9 Spalled fragments of G540 impacted at $1610 \mathrm{~m} / \mathrm{s}$. (a) Between first stage and second stage, (b) after second stage.

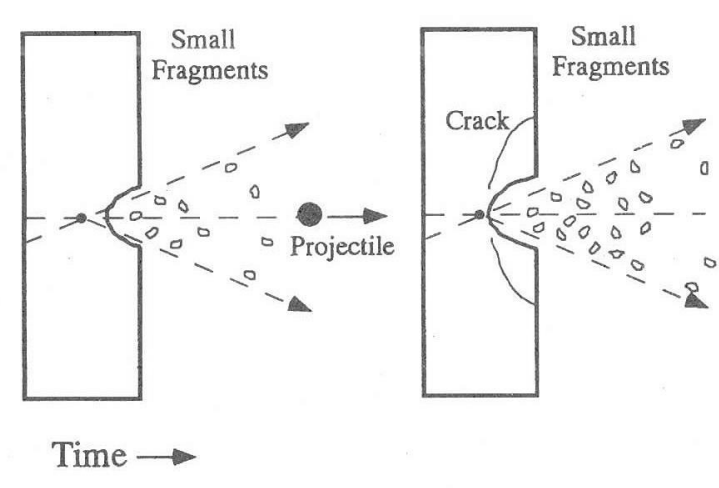

First Stage

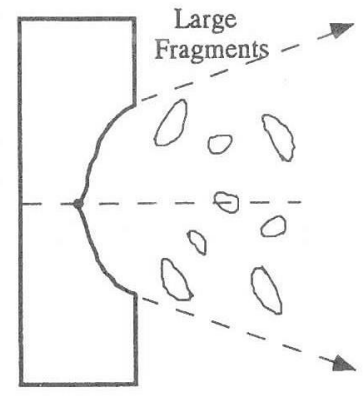

Second Stage

Fig.10 A schematic model of spallation in G540. 


\section{5. まとめ}

多結晶黒鉛材料ならびにC/C複合材料に直径 $4 \mathrm{~mm}$ のスチー ル製飛翔体を衝突させた場合に, 試料に発生するスポールを 中心とする衝撃損傷挙動について飛散容積, 応力波の伝播, 飛 散試料の形状・分布ならびに写真撮影から考察し, 次の知見 を得た。

（1）黑鉛材料のスポール臨界速度は, 静的な強度が大きく, 厚 い試料ほど大きくなる傾向がある。

（2） $2 \mathrm{D}-\mathrm{C} / \mathrm{C}$ 複合材料では, 剪断強度の弱い層があると,その 層で選択的に剥離破壊を起こす。

（3） C/C複合材料では, 飛翔体が試料を貫通する場合には試 料後面での目立った剥離破壊は観察されない。しかし, 試料 内で停止した場合には試料後面での大きな剥離破壊が観察さ れる。

（4） $\mathrm{AE}$ 用いて黒鉛材料中を伝播する衝撃波を捉えること ができる。

（5）スポール破壊によって生じる破片の寸法は, 多結晶黒鉛 の材質によって異なる。本実験範囲では, 平均してG540が大 きく,G151Aが小さく, G347はその中間であった。

（6）G540を代表として, 黒鉛材料のスポール破壊過程のモデ ルを提案した。

\section{謝 辞}

有意義なコメントを頂いた澤岡昭 東京工業大学教授に感 謝します。C/C複合材料試料の作製にあたり御尽力頂いた東 洋炭素(侏に感謝します。本研究の一部は, 科学研究費補助金 および高度化推進経費により行いました。

\section{文 献}

1) 和田 重孝, 材料科学, 29 [5] (1992) 252-257.

2）木村 雄二, セラミックス, 30 [8] (1995) 649-651.

3）浜田 晴一, 寺前 哲雄, 材料, 41 [467] (1992) 12731278 .

4) J. Cuccio, H. Fang, T. Lester, and J. Song, Proc. Automot. Technol. Dev. Contract Coordination Meetings, 27 (1990) 1613-1619.

5) Y. Akimune, Y. Katano, and K. Matoba, J. Amer. Ceram. Soc., 72 [8] (1989) 1422-1428.

6) J. Sternberg, J. Appl. Phys., 65 [9] (1989) 1529-1541

7) Y. Tanabe, T. Saitoh, O. Wada, H. Tamura and A. B. Sawaoka, Report of RLEM TIT, No.19 (1994) 223-244

8) Y. Tanabe, T. Saitoh, T. Akatsu and A.B. Sawaoka, Carbon, 33 (1995) 1547-1552.

9）田邊靖博, 佐々木健一, 赤津隆, 安田策一, 炭素, 1997, [No.176] (1997) 26-28.

10）寺前 哲夫, 浜田 晴一, 日本機械学会論文集 (A 編), 57 [535] (1991) 485-491.

11）武田 展雄, 日本複合材料学会誌, 12 [1]（1986）23-27

12) D.M. Schuter and R.P. Reed, J. Composite Materials, 3 (1969) 562-576.

13) D.A. Gorham and J.E. Field, J. Phys. D : Appl. Phys., 9, (1976) 1529-1541.

14） N. Takeda, R.L. Sierakowski and E. Malvern, J. Composite Materials, 15 (1981) 157-174.

15) R.P. Reed and D.E. Munson, J. Composite Materials, 6 (1972) 232-257.

16）「音速」,物理学事典, 培風館（1984）pp.257-258.

17) S.P. Marsh : editor "LASL Shock Hugoniot Data" University of California Press., Berkely, USA (1980) p.44 [graphite], p.213 [SUS304]

18) H. Senf, E. Strassburger and H. Rosthenhaesler, Metallurgical and Materials Applications of Shock-Wave and High-Strain-Rate Phenomena, ed by L.E. Murr, K.P. Staudhammer and M.A. Meyer, Elsevier Science B.V., England (1995) pp.163-170. 